NBER WORKING PAPER SERIES

\title{
PROSPECTS FOR IMPROVING U.S. PATENT QUALITY VIA POST-GRANT OPPOSITION
}

\author{
Bronwyn H. Hall \\ Stuart J. H. Graham \\ Dietmar Harhoff \\ David C. Mowery \\ Working Paper 9731 \\ http://www.nber.org/papers/w9731 \\ NATIONAL BUREAU OF ECONOMIC RESEARCH \\ 1050 Massachusetts Avenue \\ Cambridge, MA 02138 \\ May 2003
}

We appreciate the extremely helpful comments on an earlier draft by the editors, Adam Jaffe and Josh Lerner. The views expressed herein are those of the authors and not necessarily those of the National Bureau of Economic Research.

C2003 by Bronwyn Hall, Stuart J. H. Graham, Dietmar Harhoff, and David C. Mowery. All rights reserved. Short sections of text not to exceed two paragraphs, may be quoted without explicit permission provided that full credit including (C) notice, is given to the source. 
Prospects for Improving U.S. Patent Quality via Post-grant Opposition

Bronwyn H. Hall, Stuart J.H. Graham, Dietmar Harhoff, and David C. Mowery

NBER Working Paper No. 9731

May 2003

JEL No. K41, L00, L20, O0

\section{$\underline{\text { ABSTRACT }}$}

The recent surge in U.S. patenting and expansion of patentable subject matter has increased patent office backlogs and raised concerns that in some cases patents of insufficient quality or with inadequate search of prior art are being issued. At the same time patent litigation and its costs are rising. This paper explores the potential of a post-grant review process modeled on the European opposition system to improve patent quality, reveal overlooked prior art, and reduce subsequent litigation. We argue that the welfare gains to such a system may be substantial.

Bronwyn H. Hall

Department of Economics

University of California at Berkeley

Berkeley 94720-3880

and NBER

bhhall@econ.berkeley.edu

Dietmar Harhoff

Ludwig-Maximilians-Universität

Kaulbachstr. 45

D-80539 München

GERMANY

harhoff@bwl.uni-muenchen.de
Stuart J. H. Graham

Haas School of Business

University of California at Berkeley

Berkeley 94720-1900

graham@haas.berkeley.edu

David C. Mowery

Haas School of Business

University of California at Berkeley

Berkeley 94720-1900

and NBER

mowery@haas.berkeley.edu 


\title{
Prospects for Improving U.S. Patent Quality via Post-grant Opposition
}

\author{
Bronwyn H. Hall, Stuart J. H. Graham, Dietmar Harhoff, and David C. Mowery
}

"This is an agency in crisis, and it's going to get worse if we don't change our dynamic. It doesn't do me any good to pretend there's not a problem when there is."

James E. Rogan, appointed director of the USPTO in December 2001, as quoted in the Los Angeles Times, February 7, 2003.

\section{INTRODUCTION}

Beginning in the 1980s, a series of administrative, judicial, and legislative actions strengthened the economic value of U.S. patents and extended their coverage in such areas as computer software and "business methods." Partly as a result of these changes, patent applications in the United States continue to grow (see Figure 1) and the resources available to the patent office have not kept pace. The fraction of patents granted within two years of application has fallen from 85 percent in the early 1990s to about 70 percent in the late 1990s. At April 2002 hearings before the House Subcommittee on Courts, the Internet and Intellectual Property, Commissioner Rogan stated that "Average pendency surpassed 24 months in 1999, and we expect it to average 26.5 months this year (2002)."

A second consequence of these changes has been an increase in patent litigation and a more recent increase in patent litigation rates. In a study of patent litigation between 1978 and 1995, Lanjouw and Schankerman (2002) found that the rate of litigation rose only slightly between the 1978-84 and the 1991-95 periods, from 19 to 21 suits per thousand patents, with some variation across technology areas. Somaya (2002a) suggests that this rate rose again in the late 1990s. In a new and comprehensive study of patent litigation focusing on cases that terminated in 1998-2000, Allison et al. (2003) report a litigation rate of approximately 32 suits per thousand patents. Whether or not litigation per patent issued has increased substantially, the fact remains that the absolute amount of litigation has grown enormously, increasing both the private and public costs of the system as a whole.

Although many of the administrative, legal and judicial changes in policy affecting patent validity, examination, and value were undertaken at the behest of the U.S. business community, concerns have been raised about the potential economic burdens of lowquality patents in an environment of greater deference to the rights of the patentholder (Merges 1999; Barton 2000; Kingston 2001). It is therefore not surprising that a number of experts have suggested that the U.S. patent examination system does not currently impose a sufficiently rigorous review of patent and nonpatent prior art, resulting in the issuing of patents of considerable breadth and insufficient quality and that this problem has worsened in recent years. Many of these critics advocate the reform or extension of procedures that would enable interested parties other than U.S. Patent and Trademark 
Office (USPTO) examiners to bring relevant information to bear on this process either before or shortly after the issue of a patent

The present paper reviews the prospects for improving the operation of the patent system and lowering its cost by changing the administrative process at the USPTO. At present, the primary administrative procedure for a challenge to the validity of a U.S. patent is the "reexamination" proceeding, which may be initiated by any party during the life of the patent. A more elaborate and adversarial procedure for challenging the validity of patents in the immediate aftermath of their issue is the "opposition proceeding" that is used by the European Patent Office (EPO). A number of scholars, both legal and economic, have advocated the introduction of such a system in the United States, or a strengthening of the re-examination system in order to improve the quality of patents and to increase the likelihood that relevant prior art is brought to bear, especially in new subject matter areas (see Hall 2003 for a summary of these views). In this paper we consider the likely effects of introducing such an post-grant review process in the U.S. patent system, focusing in particular on the ability of such a process to improve the "quality" of patents and reduce the length of time that the current reliance on litigation requires to ascertain the validity of the relatively valuable patents that are contested in court. Our assessment of the benefits and costs of a U.S. post-grant patent review system draws on our previous work (Graham et al. 2003), as well as that of Janis (1997) on alternatives to the re-examination procedures and Levin and Levin (2002) for models of strategic litigation and opposition behavior.

We begin by reviewing the current causes of concern about the operation of the U.S. patent system, focusing on the patent quality issues that such a system might be designed to improve. We then describe the institutional background and administrative structure of the U.S. and European patent systems. Readers who are already familiar with the patent system or who are not interested in the institutional detail may wish to skip this section. The final sections of the paper compare the operation of the two patent systems and then present a simple welfare analysis of the expected costs and benefits of introducing a more adversarial administrative challenge system.

\section{THE PROBLEM}

\section{Patent quality}

What do we mean by patent quality? From the perspective of economic welfare, granting the property right described by a patent involves trading off the gain from providing an incentive for innovation against the deadweight loss implied by the possibility of a monopoly during the patent term. The statutory definition of a patentable invention is that it be novel, non-obvious, and have utility. ${ }^{1}$ Both the economic and legal view suggest that high quality patents are those which describe an invention that is truly "new," rather than an invention that is already in widespread use but not yet patented. ${ }^{2}$ See Table 1 for some

\footnotetext{
${ }^{1}$ See Lunney (2001) for an argument that the non-obviousness test has been weakened since the creation of the Federal Circuit Court of Appeals in 1982.

${ }^{2}$ Presumably, if the invention has already been reduced to practice by others, the potential gain from incenting an inventor is zero, so we are left only with the deadweight loss from monopoly.
} 
examples of patents that appear to violate this definition, mostly because there is prior art that is not easily searchable in written form.

Besides the three statutory requirements, a fourth criterion for granting a patent on an invention is that the patent application must disclose sufficient details about the invention. Patents thus serve another social purpose, since these disclosures in the published patent can facilitate knowledge spillovers to others who might use or improve upon the invention. Another criterion for a "high-quality patent" therefore is that it enable those "skilled in the art" to comprehend the invention well enough to use the patent document for implementation of the described invention. This dimension of patent quality, however, is less likely to be affected by post-grant opposition proceedings.

From a social welfare perspective, an important characteristic of a high quality patent is that there be relatively little uncertainty over the breadth of its claims, i.e., over what specific features of a technical advance are claimed under the terms of the patent, as well as whether these claims are likely to be upheld in legal proceedings following the issue of the patent. Uncertainty about the validity of a patent has several potential costs: such uncertainty may cause the patentholder to underinvest in the technology, it could reduce investment by potential competitors in competing technical advances, and it may lead to costly litigation after both the holder and potential competitors have sunk sizable investments.

\section{Consequences of low patent quality}

Although some scholars, notably Lemley (2001), have argued that the costs of having higher quality patents may exceed the benefits, recent experience suggests that there are some unintended consequences in the form of complicating property rights and feedback effects. In this section we review the arguments for increasing patent quality.

"Low-quality patents" can create considerable uncertainty among inventors or would-be commercializers of inventions and slow either the pace of innovation or investment in the commercialization of new technologies. Lerner (1995) has shown that fear of litigation may cause smaller entrant firms to avoid areas where incumbents hold large numbers of patents. Such "entry-avoidance" may be rational and even welfare-enhancing if the incumbents' patents are known for certain to be valid, but low quality patents held by incumbents may also deter entry into a technological area if the costs of invalidating the patents is too high. In these circumstances, technological alternatives may not be commercialized and consumer welfare suffers.

The lack of relatively rapid processes for resolving patent validity and ensuring higher patent quality also may slow the pace of invention in fields characterized by "cumulative invention," i.e., those in which one inventor's efforts rely on previous technical advances or advances in complementary technologies. But if these previous technical advances are covered by patents of dubious validity or excessive breadth, the costs to inventors of pursuing the inventions that rely on them may be so high as to discourage such "cumulative" invention. Alternatively, large numbers of low-quality patents may dramatically increase the level of "fragmentation" of property rights covering prior- 
generation or complementary technologies, raising the transaction costs for inventors of obtaining access (e.g., through licenses) to these technologies. Finally, the issue of a large number of low-quality patents will increase uncertainty among inventors concerning the level of protection enjoyed by these related inventions, which in turn will make it more costly and difficult for inventors to build on these related inventions in their own technical advances.

The issuance of low-quality patents also is likely to spur significant increases in patent applications, further straining the already overburdened examination processes of the USPTO. A kind of vicious circle may result, in which cursory examinations of patent applications result in the issue of low-quality patents, which triggers rapid growth in applications, further taxing the limited resources of the USPTO, further limiting the examination of individual applications, and further degrading the quality of patents.

Recent decisions by the Court of Appeals for the Federal Circuit (CAFC), the specialized appeals court for patent cases, concerning the validity of "important" patents (those deemed sufficiently valuable by patentholder or competitor to litigate and appeal) create still another reason for serious consideration of a nonjudicial process for post-issue validity challenges. For example, in 2002 the CAFC ruled that the PTO had incorrectly rejected two applications for "obviousness," arguing that if an examiner rejects an application using "general knowledge," that knowledge "must be articulated and placed on the record." ${ }^{3}$ According to deputy commissioner Esther Kepplinger, this means "we can't reject something just because it's stupid." This decision could significantly weaken the level of scrutiny provided by the already costly and overcrowded patent-litigation system. A system that enabled third parties (including competitors) to bring such knowledge (in the form of written prior art) to bear on the patent could help in making an obviousness determination.

The U.S. patent system, no less than those of other advanced industrial economies, is very much a political creation. Its development and frequent alterations at the hands of the U.S. Congress reflect changes in the balance of political power among corporate inventors, independent inventors, the broader research community, and the general public. It is hardly an accident, after all, that the most recent series of changes in the U.S. and international patent systems were undertaken by U.S. political actors during the throes of the "competitiveness crisis" of the 1980s. And the increased economic stakes in intellectual property resulting from these policy changes, as well as the broader shift to a "knowledge-based economy," are likely to complicate reforms of such potentially farreaching scope as the introduction of a more elaborate system for post-grant validity challenges (indeed, the re-examination process that we discuss below was considerably weakened during debate over its passage by the Congress). Nevertheless, consideration of

\footnotetext{
${ }^{3}$ This decision presumably made it more difficult to reject such patents as US 6368227, the patent on a swinging method that uses a technique known by children for years, but not placed "on the record." Note that this particular patent has been subject to a re-examination request of the U.S. Patent Commissioner because of the publicity it received. The problem with patents like this is not necessarily that they are enforceable in the courts, but that they clog the system and raise its total cost.

${ }^{4}$ As quoted on the Los Angeles Times, February 7, 2003.
} 
any such reforms must begin with an analysis of their operation in other industrialeconomy patent systems. The remainder of this paper examines the EPO opposition system and compares its operation and outcomes with those of the existing administrative process for patent-validity challenges in the United States, the "re-examination." therefore,

\section{INSTITUTIONAL BACKGROUND}

The U.S. and European patent systems have similar aims and requirements for patentability but differ in the allowable subject matter and in their administrative procedures. As we noted earlier, the U.S. system requires that an invention ("process, machine, manufacture or composition of matter") satisfy four requirements to be patentable: adequate disclosure, novelty, usefulness, and nonobviousness. In Europe, firms and individuals have been able since 1978 to submit a single application to the European Patent Office that specifies up to 24 national jurisdictions in which they desire patent protection for an invention. Under the EPO regime, the patentability requirements -- adequate disclosure, novelty, industrial application, and inventive step -- are broadly similar but not identical to those of the United States.

The median time between application and patent issue in the U.S. system during the 1980s and 1990s was 18 months to 2 years (with a long "tail" of patent applications with much longer pendency), and in the EPO was slightly more than 4 years. As part of the patent system harmonization legislated in the American Inventors Protection Act of 1999, the United States instituted a policy of publication 18 months after application in November 2000 for many patents with applications pending in jurisdictions outside the United States. In contrast, EPO applications have always been published with an 18month lag, regardless of whether they have issued.

Both systems have a postgrant procedure through which the validity of the patent can be challenged by other parties, but the two patent systems' postgrant challenge procedures differ significantly. In both systems, interested parties can also bring suit in court over infringement and validity (with some restrictions as to when a suit can be filed). We discuss these administrative processes for postgrant challenges in the following sections.

\section{USPTO Examination and Reexamination Procedures}

In the United States, inventors may claim a utility patent by making application to the USPTO. Before a patent issues, the USPTO is charged with ensuring that the invention is adequately specified, covers patentable subject matter, and is useful, novel, and nonobvious. Procedurally, the application must be filed within 1 year of the invention's public use or publication, contain an adequate description with one or more claims, and be accompanied by the payment of a fee.

The USPTO patent examiner is the arbiter of the patentability, novelty, usefulness, and nonobviousness requirements cited above, judging these standards against the "prior art," i.e., prior inventions, in the field. Prosecution of the patent has been characterized as a "give-and-take affair," with negotiation and renegotiation between the patentee and the 
examiner that ordinarily continues for 2-3 years (Merges et al.., 1997). The costs of prosecuting a patent through the USPTO range from $\$ 5,000$ to $\$ 100,000$ (including the USPTO issue fee), depending on the nature of the technology.

Reexamination, originally envisioned as an alternative to expensive and time-consuming litigation, was created by the 1980 Bayh-Dole Act. The legislative history of this act suggests that the reexamination was intended to be a mechanism that would be less expensive and less time-consuming than litigation. ${ }^{5}$ During the legislative process, however, the act was purged of its intended adversarial characteristics, reducing the usefulness of the procedure for opponents of a given patent.

Procedurally, the reexamination proceeding permits the patent owner or any other party to notify the USPTO and request that the grounds on which the patent was originally issued be reconsidered by an examiner. Initiation of a reexamination requires that some previously undisclosed "new" and relevant piece of prior art be presented to the agency. Under the statute, a relevant disclosure must be printed in either a prior patent or prior publication — no other source can serve as grounds for the reexamination.

After being initiated by notification and the payment of a fee to the USPTO, the reexamination goes forward only if the USPTO finds a "substantial new question of patentability." Such a determination was intended by lawmakers to prevent the reopening of issues deemed settled in the original examination (Merges, 1997). The USPTO must make this determination within 3 months of the request and, having made the determination, must notify the patent owner.

When the owner is not the reexamination proponent (about half the cases), the patentee is allowed to file a response to the newly discovered prior art within 2 months. If the owner chooses to respond, the requester is afforded an opportunity to reply within 2 months. By choosing not to respond, the owner can limit the requester's participation in the process. The reexamination is an ex parte proceeding between the patent owner and the USPTO that provides limited opportunities for third-party involvement. ${ }^{6}$

The party requesting a re-examination is entitled to notify the USPTO of the triggering "prior art," to receive a copy of the patentee's reply to the reexamination (if any), and to file a response to that reply. The owner's role in the process is much more involved: The

5 Our evidence (Graham et al. 2003) suggests that the average reexamination takes less than 2 years, slightly shorter than the average duration of a patent lawsuit (31 months). But this difference is not large (especially in view of the high variance of the "average duration" estimate for a trial); some observers have criticized the reexamination system for not having provided a fast and cheap alternative to trial.

6 An alternative reexamination procedure, the inter partes reexamination, was enacted by the U.S. Congress in 1999 (see the American Inventors Protection Act, codified in 35 USC 311-318. Several commentators have questioned the efficacy of the inter partes reexamination on grounds that it allows the third-party requestor limited opportunities of involvement, prevents any adverse findings of the USPTO from being appealed to the courts, and also precludes the raising of any questions of validity on grounds that were, or may have, been raised during the inter partes reexamination from being litigated in the courts (Neifeld 2000). The USPTO reports no inter partes re-examination requests in 2000 and one in 2001, suggesting that the procedure has been little used in practice. 
reexamination statute contemplates a second examination, with the same type of "giveand-take" negotiation between owner and patent office that occurs during the initial issuance of a patent. The examiner remains the final arbiter of the process, and it is not uncommon for the original examiner to be assigned the follow-up reexamination, thus putting the question of whether prior art was overlooked in the hands of the same government official who was responsible for ensuring that no prior art was overlooked in the previous search.

Once the reexamination goes forward, however, the statute requires that the Commissioner make a validity determination. The original patent is afforded no statutory presumption of validity in the proceeding, although the practice of assigning reexaminations to the original examiner may produce such a presumption. The reexamination cannot be abandoned or postponed to await the result of concurrent litigation proceedings, although it may be stayed during other USPTO proceedings, including reissue or interferences. A reexamination may result in the cancellation of all or some of the claims in a patent or the confirmation of all or some of the claims. Nothing in the reexamination procedure can expand the scope of the original patent's claims, but claims may be amended or new claims added during the renegotiation between the patent owner and the examiner.

In summary, for parties seeking to invalidate an issued patent, the reexamination procedure involves considerable costs and risks. The filing fee for the reexamination is substantial, and practitioners estimate the average costs of a reexamination at $\$ 10,000$ $\$ 100,000$ depending on the complexity of the matter. Although the costs of a reexamination are lower than those of litigation (\$1-3 million), the third-party challenger in reexamination is denied a meaningful role in the process, and the patentholder maintains communications with the examining officer, offering amendments or adding new claims during the reexamination. Reexamination may make it more difficult for challengers to prevail in patent-validity litigation, because juries tend to give added weight to reexamined patents. Moreover, the Court of Appeals for the Federal Circuit has indicated that claims confirmed by the reexamining officer present added barriers to a successful contest. ${ }^{7}$ As a result, challengers face powerful incentives to forego reexamination in favor of litigation, a process that may well be more expensive, more time-consuming, and less expert in testing post-issue validity.

\section{Patent Litigation in the United States}

In the United States, post-issue validity can also be tested in court. Procedurally, litigation differs markedly from the reexamination procedure. Unlike the reexamination procedure, litigation is an adversarial proceeding in which the litigant may elect to have the case heard by either a judge or a jury. Because patent suits generally arise from a charge of infringement by the patent owner, the patentee exerts considerable control over the timing of enforcement and litigation in a patent dispute. ${ }^{8}$

7 Kaufman Company v. Lantech, Inc., 807 F.2d 970 (CAFC, 1986) (suggesting that evidentiary burdens are likely higher for challengers after reexamination).

8 This owner initiation occurs in many cases in which declaratory validity determinations are being sought by a challenger third party: These suits, which make the patentee the defendant, are often 
Legal standards create a relatively hostile environment in the federal courts for challengers seeking to invalidate an issued patent. Under the statute, patents are "born valid," enjoying a presumption of validity during the court proceedings. Furthermore, the evidentiary standard for proving a claim invalid is "clear and convincing" evidence, a standard considerably higher than the mere "preponderance" of proof required in the typical civil suit. Because judges and juries may have limited technical expertise, these presumptions and evidentiary barriers create high costs for challengers. The "pro-patent" judicial philosophy promulgated by the CAFC since its creation has compounded these barriers: According to one study, successful challenges to patent validity fell from 50 percent to 33 percent in the years after the creation of the CAFC (Lemley and Allison, 1998).

Direct costs in litigation are also high compared with those of reexamination. Estimates of legal costs in patent litigation run from half a million dollars to three million dollars per suit depending on the amount at risk (AIPLA, 2001) or to $\$ 500,000$ per claim at issue, per side (Barton, 2000). One important driver of these costs is the extensive use of pretrial discovery. The lag between filing a patent suit and reaching a resolution can also be considerable: one study estimates the average length of a District Court patent suit at 31 months (Magrab, 1993).

But, in fact, very few patent suits actually go to trial, as reported in Lanjouw and Schankerman (2002), who find that approximately 95 per cent of all patent suits settle either before or during trial. 78 per cent settle even before the pre-trial hearing, an additional 16 per cent settle before trial, and one per cent settle during trial. The median length of time to settlement is 8 months, 16 months, and 25 months, respectively, implying that the average or median time to a litigation outcome is somewhat less than the 31 months reported by Magrab. This does not mean that litigation is not costly, since according to the surveys conducted by the AIPLA, about half of the estimated legal costs of litigation are incurred before the end of the discovery phase (AIPLA, 2001). It also does not mean that the social costs of a patent are avoided, since settlement before trial is likely to lead to a collusive outcome.

\section{EPO Examination and Opposition Procedures}

Patent protection for European signatories to the European Patent Convention states can be obtained by filing several national applications at the respective national patent offices or by filing one EPO patent application at the European Patent Office. The EPO application designates the EPC member states for which patent protection is requested. ${ }^{9}$ The total cost of a European patent amounts to approximately $€ 29,800$, roughly three

initiated only after a demand by the patentholder for the challenger to stop infringing the patent, thus putting the initial move in the hands of the patentholder.

9 The Convention on the Grant of European Patents, also referred to here as the European Patent Convention (EPC) was enacted in October of 1973. It is the legal foundation for the establishment of the EPO. The full text of the convention is available at http://www3.european-patentoffice.org/dwld/epc/epc 2000.pdf. 
times as much as a typical national application..$^{10}$ Thus, if patent protection is sought for more than three designated states, the application for a European patent is less expensive than independent applications in several jurisdictions. This cost advantage has made the European filing path particularly attractive for applicants selling goods and services in multiple European markets. Increases in the number of patent applications and grants have given the EPO a level of economic importance that now resembles that of the USPTO.

EPO patent grants are issued for inventions that are novel, mark an inventive step, are commercially applicable, and are not excluded from patentability for other reasons. After the filing of an EPO application, The Hague EPO office produces a "search report" for the applicant. The search report describes the state of prior art regarded as relevant according to EPO guidelines for the patentability of the invention, i.e., it contains a list of references to prior patents and/or nonpatent sources. Unlike in the U.S. system, applicants at the EPO are not required to supply a full list of prior art (see Michel and Bettels, 2001, 191ff). Within 6 months after the announcement of the publication of the search report in the EP Bulletin, applicants can request the examination of their application. This request is a compulsory prerequisite for the patent grant. If examination is not requested, the patent application is deemed to be withdrawn. Eighteen months after the priority date the patent application is published. At this point, the application is normally under examination; thus the patent owner is generally required to reveal some information about his/her invention before the grant of the patent and even if no patent is ever issued.

After examination (if requested) has been performed, the EPO either informs the applicant that the patent will be granted as specified in the original application or requires the applicant to agree to changes in the application that are necessary for the patent grant. In the latter case, a negotiation process similar to that in the U.S. system follows. Once the applicant and the EPO have agreed on the scope of the allowable subject matter, the patent issues for the designated states and is translated into the relevant national languages. If the EPO declines to grant a patent, the applicant may file an appeal. Within 9 months after the patent has been granted, any third party can oppose the European patent centrally at the EPO by filing an opposition against the granting decision. The outcome of the opposition procedure is binding for all designated states. If opposition is not filed within 9 months after the grant, the patent's validity can only be challenged under the legal rules of the respective designated countries. The EPO opposition procedure is thus the only centralized challenge process for European patents.

An EPO patent opponent must file an opposition with the EPO and present evidence that the prerequisites for patentability were not fulfilled, e.g., the opponent must show that the invention lacked novelty and/or an inventive step or that the disclosure was poor or

10 At the time of writing the exchange rate is approximately 0.93 euros per dollar. As in other patent systems, the official patent office fees are a relatively small part of the costs (in this case $€ 4,300$. Professional representation before the EPO amounts to $€ 5,500$ on average, whereas translation into the languages of eight contracting states requires $€ 11,500$. Renewal fees for a patent maintained for 10 years amount to roughly $€ 8,500$. See "Cost of an average European patent as at 1.7.99", http://www.european-patent-office.org/epo/new/kosten_e.pdf (Jan. 14, 2002). 
insufficient. At the EPO, an opposition division determines the outcome. The examiner who granted the patent is a member of the three-person opposition chamber but may not be the chairperson. The opposition procedure can have one of three outcomes: The patent may be upheld without amendments, it may be amended, or it may be revoked. Data on opposition outcomes reported in Graham et al. (2003) indicate that revocation occurs in about one-third of all opposition cases.

Another interesting aspect of the opposition procedure concerns the restrictions imposed by this process on the opponent's ability to settle "out of court." Once an opposition is filed, the EPO can choose to pursue the case on its own, even if the opposition is withdrawn. Thus the opponent and patentholder may not be free to settle their case outside of the EPO opposition process once the opposition is filed. This provision of the opposition proceeding may discourage its use by opponents seeking to force patentholders to license their patents.

Both the patentholder(s) and the opponent(s) may appeal the outcome of the opposition procedure. The appeal must be filed within 2 months after receipt of the decision of the opposition division, and it must be substantiated within an additional 2 months. The Board of Appeal affords the final opportunity at the EPO to test the validity of the contested European patent. Both parties can bring expert witnesses into the proceedings, and there are various options for having deadlines extended. Graham et al. report that the median duration of the challenge procedures (opposition and any appeal) is about three years, although there is considerable variation in the duration of individual cases (the interquartile range is also about three years).

The official fee for filing an opposition is $€ 613$; for filing an appeal against the outcome of opposition, the fee is $€ 1022$. However, the total costs to an opponent or the patentholder are much higher. Estimates by patent attorneys of the costs of an opposition range between $€ 15,000$ and $€ 25,000$ for each party. Patent attorneys we interviewed agreed that opponents have limited ability to drive up the patentholders' costs by filing an opposition (in contrast to litigation in the United States), since attorney fees are regulated in most European countries, including Germany, where many patent lawyers who have the required $\mathrm{EPO}$ registration reside.

\section{Patent Litigation in Europe}

One desirable feature of the EPO opposition system is its centralized structure within the fragmented European legal system for patent challenges. As we noted earlier, patent litigation affecting EPO patents is conducted at the national level. The centralized nature of the EPO opposition process thus arguably is more important in this context than in the United States, where the federal courts operate as a more unified system. Nonetheless, a full evaluation of the effects of the EPO opposition system requires some consideration of the possibilities for litigation, which are not precluded by the opposition proceeding.

There have been very few systematic studies of patent litigation within the various European nations, and we therefore confine ourselves to a brief review of the few facts that are known. Outcomes in the "local" litigation processes involving EPO patents are 
restricted to the "local" level, e.g., the patent may be invalidated in Spain, but this does not affect its validity in Italy. During the past decade, national patent courts have increasingly taken evidence and decisions from litigation in other European nations into account, but no systematic study has analyzed such legal "spillover" effects (Stauder, 1996; Stauder et al.. 1999).

The differences among national jurisdictions within Europe are enormous, requiring substantial investments in each national suit and driving up the costs of challenging the national patents emerging from an EPO grant in several of the designated states. The costs of litigation in any national court have been estimated to be between $€ 50,000$ and $€ 500,000$, depending on the complexity of the case. This cost structure makes an attack at the European level with the opposition procedure particularly attractive for a current or potential competitor of the patentholder. The litigation rate (computed as the number of cases for which a suit is filed divided by the number of patents) in most European countries is roughly 1 percent, slightly lower than the 1.9 percent reported for the United States (Stauder, 1996, 1989; Lanjouw and Schankerman 2001). However, recent estimates by Cremers (2003) suggest that the litigation rate may as high in Germany as in the United States, on the order of 2.1 per cent. ${ }^{11}$ At this juncture, all that can be said is that the quantitative evidence is too sparse to conclude from these figures that the existence of the opposition mechanism leads to a reduction in litigation or in litigation cost.

\section{$4 \quad$ Comparing the two systems}

In Graham et al. (2003), we compared the operation of the post-issue re-examination and opposition systems for challenging patent validity in the U.S. and drew some conclusions about the differences between an ex parte system such as is currently found in the U. S. and an inter partes system used in Europe. First, the U.S. reexamination procedure differs dramatically from the EPO opposition procedure in virtually all of its features. The two most important are that re-examinations are much less common, with an overall average rate of $0.2 \%$, in contrast to the European opposition rate of about $8 \%$, and that the identity of the party requesting a reexamination is the patent owner in at least $44 \%$ of the cases, lowering the effective rate even more. This characteristic of reexamination hardly qualifies it as the sort of adversarial procedure that EPO oppositions represent.

We also found that EPO oppositions resolved validity challenges more slowly than USPTO reexamination proceedings. Indeed, opposition proceedings in some cases (and almost certainly in important, complex cases with numerous opponents, appeals, etc.) may well take as much time to be resolved as litigation in the U.S. system. Nonetheless, the higher frequency of EPO opposition as compared to U.S. re-examination or litigation is at least consistent with the hypothesis that the opposition process handles many more

\footnotetext{
${ }^{11}$ Using data from court filings in Mannheim and Duesseldorf, Cremers identifies 715 patent infringement cases involving 905 patents during the 1993-1995 period. These courts account for about 55-60 per cent of all cases filed in Germany. The three year average of EPO patents issued since 1980 that included Germany as one of the covered regions is about 71,000 , for a litigation probability of about 2.1 per cent, assuming the process is stationary.
} 
legal disputes over patent validity than are addressed by the U.S. reexamination process and at a lower cost than the U.S. litigation process. ${ }^{12}$

Our analysis of the outcomes of the re-examination and opposition system outcomes confirmed that the adversarial nature of the opposition system was more likely to lead to outcomes unfavorable to the patent holder. In Table 2 we show the distribution of outcomes for all re-examinations and all oppositions of patents over the past twenty years. It is clear from the table that patent revocation is much more likely when a patent is opposed in Europe (one in three is revoked) than when a patent is re-examined in the United States (only one in ten is revoked). Combined with the lower probability of reexamination, the overall probability that a patent is revoked via a post-grant administrative challenge is 3 percent in Europe and essentially zero ( 0.02 percent $)$ in the United States. Conversely, re-examination is more likely than opposition to lead to amendment of the patent, whether or not the patent owner initiated the process.

Our analysis also indicated that patent amendment, rather than revocation, is more likely for oppositions in relatively new fields of inventive activity, for more "complex" patents, or for oppositions in which numerous opponents participate. Because we lack evidence on the extent to which oppositions are followed by litigation in the European patent system, we were unable to determine whether the lack of any "speed advantage" for oppositions in resolving patent disputes quickly is offset by a reduction of litigation rates associated with oppositions. The EPO system may offer few advantages over the U.S. system for post-issue patent challenges, but we cannot address this issue without analyzing litigation data for both the U.S. and European systems. Any truly comprehensive assessment of the social costs and benefits of the two challenge systems requires that we consider both the "patent office" processes of postgrant challenge (opposition or reexamination) and litigation. Nevertheless, we present a simple version of such an analysis in the next section of the paper.

Although an EPO opposition must be filed within 9 months of patent issue, it does not reach a conclusion more rapidly than the US re-examination procedure, if we estimate the total time lag as the length of time from patent application date to final resolution. The average lag between application date and the initiation of a challenge is substantially greater within the US re-examinations than in the EPO oppositions, but this difference reflects the different time limits on the initiation of such proceedings. Should we conclude from these comparative data that the longer lags in the EPO opposition system imply a lengthier period of uncertainty, legal expense, and therefore, a higher welfare burden within the innovation systems of these economies? Such a conclusion is unfounded, since it relies on a characterization of the re-examination and opposition proceedings as analogous in their characteristics, rigor, and outcomes. The data presented above on the identity of the parties initiating re-examinations, as well as the abundant evidence discussed earlier of significant procedural differences between the reexamination and opposition processes, should dispel any such analogies. Any such

${ }^{12}$ The latter statement is premised on the argument that more oppositions than suits are filed partly because they are lower cost. 
comparison of challenges must incorporate data on the next stages of these challenges, which in both Europe and the United States involve litigation.

One of the concerns that is often raised about both litigation and post-grant administrative challenges is that they may be used by firms with deep pockets to harass smaller firms and independent inventors. ${ }^{13}$ Although re-exam requests are slightly more likely if the patent is held by an independent inventor, there is little if any evidence that independentinventor patents are significantly more prone to EPO oppositions that other patents. This means that the opposition system in Europe is not being used by large players to harass small inventors.

Nevertheless, the possibility of some strategic use of the system by competing firms cannot be ruled out. For example, Harhoff and Hall (2002) find that in the hair care industry, a German firms systematically oppose the patents of their multinational competitors and are not opposed in turn. Whether this is due to greater expertise and knowledge of the prior art or to greater familiarity with the use of the opposition system as a weapon is not clear.

\section{WELFARE GAINS FROM IMPROVED POST-GRANT REVIEW}

Would introducing an adversarial challenge system simply add another level of costly litigation to what is already there? Or does it have the potential to reduce the subsequent litigation? Answering this question is a complex task, given the difficulty of predicting the response of firms and individuals to a rather radical change in the administration of the patent system. Nevertheless, it is possible to perform some simple welfare computations based on plausible assumptions about the value of patent validity and the known costs of both the European and U.S. patent systems. As Levin and Levin (2002) argue in their discussion of the same issue, successful patent opposition is likely to reduce subsequent patent litigation substantially, increasing social welfare, but opposition itself brings forward cases that would not have gone to litigation and affects the terms on which firms are able to license the technology embedded in patents. They conclude that on balance there are likely to be substantial welfare gains from the introduction of an opposition system. In this section of the paper we present our own analysis of the consequences of this change and reach a similar conclusion.

Successful opposition should reduce litigation because invalid patents could not then be litigated, although this might require a somewhat circumscribed appeals process that does not allow recourse to the courts. Unsuccessful opposition may still lead to litigation later and, unless barred by statute, successful opposition might also lead to later litigation on the part of the former patentholder. The net result of this is fewer suits filed, and possibly fewer collusive settlements based on the threat of a suit, although there might be an increase in collusive settlements based on the threat of opposition.

\footnotetext{
${ }^{13}$ In fact, according to data reported by Lanjouw and Schankerman (2002) it is the other way around in the United States: small firms and independent inventors are far more likely to file infringement suits than larger firms.
} 
The computation shown below makes these ideas more precise. We compute the social benefits and costs of introducing an opposition system under a few simple stylized assumptions. Although the precise numbers should be viewed somewhat sceptically, the order of magnitudes are such as to suggest that there may be substantial social gains from such a system. The total cost of the system per year is assumed to be given by

$$
C=c_{o} \phi N
$$

where $c_{o}$ is the cost of an opposition, $\phi$ is the rate of opposition, and $N$ is the total number of patents issued in a year. We assume a range of costs between $\$ 100,000$ per opposition (the European estimate) and $\$ 500,000$ (the cost assumed by Levin and Levin 2002), and a range of opposition rates between two per cent (very conservative) and ten per cent, which is approximately the rate in Europe.

Computing the benefit of the system requires some assumptions about the effects of opposition outcomes on the costs associated with avoiding litigation, collusive pre-suit settlements, and the exercise of monopoly power. We write the benefit as

$$
B=b_{o} \phi N
$$

with $b_{o}$ the cost avoided by each opposition and $\phi$ and $N$ as before. $b_{o}$ has three components, corresponding to the three possible outcomes of the opposition, revocation, amendment, or rejection. In order to estimate these components, we assume that the opposition and appeals boards take the correct decision when they revoke or amend a patent or when they reject an opposition.

In the case of revocation that means that the patent should never have been granted, and that its existence may create excessive market power. Suppose that in litigation, the same correct outcome would be obtained, i.e., the patent right would be destroyed. Then -- as long as the respective case would have ended up in litigation -- opposition will simply preempt later litigation; the welfare effect is then to reduce the number of cases in litigation, at the cost of an opposition proceeding. We assign an average social value of $\$ 2$ million dollars to avoided litigation, based on the estimates provided by AIPLA (2001) for legal costs plus an addition for the direct costs to the firms involved and the cost of court services.

Since the parties may have an incentive to settle, not all cases will actually be litigated (Lanjouw and Schankerman 2002). But in this case, if the correct outcome would have been a revocation, a settlement between the parties will be socially inefficient, because it typically maintains the patent for the proprietor and allows the other party in litigation to have an exclusive license. This amounts to a case in which the two parties collusively maintain patent protection, which may impose considerable welfare costs on society. ${ }^{14}$

${ }^{14}$ This is the reason why the European Patent Office is entitled to pursue opposition cases on its own, even if the two parties wish to settle the case. Thus this feature of an opposition system can be expected to increase social welfare. 
The welfare costs of such an agreement depend on the value of the patent right and demand conditions. As our base case, we assume that high value patents which are attacked in the opposition procedure have an average value of $\$ 4$ million and therefore a monopoly welfare loss of $\$ 2$ million. ${ }^{15}$ For example, Harhoff, Scherer and Vopel (2003) compute an average value of about (1977) DM 400,000 for patents of German proprietors. They also estimate regressions which indicate that opposed patents which survived opposition are worth about ten times this amount. We assume that patents which were opposed but did not survive opposition would generate the same level of profits as patents that withstood opposition. In 2003 terms (assuming a 4 percent growth rate), the average value of an attacked patent would then be roughly 5.76 million euros $\left(=1.04^{27} 400,000 / 2\right)$. A conservative estimate of the value of the attacked patent is therefore $\$ 4$ million on average, with welfare losses in the monopoly case of $\$ 2$ million.

In the case of amendment (where usually claims are narrowed), a similar argument holds, although the avoided litigation cost is likely to be much smaller. The results from opposition rejection are more ambiguous. It may reduce uncertainty about the patent validity and therefore reduce subsequent litigation, but this is by no means certain. In our base case, we assume no effect, and we also evaluate a variant where there is increased social cost due to an increase in litigation probability when opposition is rejected.

In Table 4 we show the benefit cost computation under a variety of different scenarios. There are three panels, each corresponding to a set of assumptions about outcome probabilities: the first uses the probability that a U.S. patent is found valid during litigation reported by Allison and Lemley (2002). The second uses the observed opposition outcome probabilities for the EPO system and the third uses the observed reexamination outcome probabilities of the USPTO system, both given in Table 2. The latter choice is very conservative and an opposition system is unlikely to lead to patent revocation probabilities as low as 11 per cent. For each of these three outcome scenarios, we report five computations, three using a (comparatively) low opposition cost and two using the higher estimate of $\$ 500,000$ that was used by Levin and Levin. We also experiment with assuming a social cost for rejection and an avoided cost for patent amendment as well as for patent revocation.

Almost all of the scenarios yield benefit-cost ratios well in excess of unity, with the exception of some of those that use the re-examination outcome probabilities. The lowest ratios for each panel are for the high opposition cost cases. We conclude that unless the opposition system is very expensive to operate and yields results similar to those now obtained with the re-examination system, it would be likely to generate substantial welfare gains.

\section{CONCLUSIONS AND FURTHER QUESTIONS}

The determinants and characteristics of patent challenge procedures are an important issue in any assessment of the U.S. or other industrial economies' intellectual property systems. In a "knowledge-based" economy, intellectual property systems are constantly

\footnotetext{
${ }^{15}$ With linear demand, the welfare loss from monopoly will be one half of the monopoly rents.
} 
challenged by the advance of technology, a process that among other things creates new artifacts to which the necessarily backward-looking patent system must respond. A "knowledge-based" economy also is one in which the high political salience of national and global intellectual property systems means that they are the focus of political lobbying to strengthen, adapt, or weaken specific features of intellectual property regulation, administration, and law to favor particular interests. Both of these forces have been at work within the U.S. intellectual property system during the past quarter-century; a period of significant strengthening of patentholder rights has triggered a debate over the appropriate level and limits of such rights. Moreover, this debate has important transAtlantic and global echoes and analogues.

As the knowledge-based economy has evolved in the United States and elsewhere, it has become clear that such evolution brings with it increasing attention to the ownership of "knowledge" in the form of intellectual property by firm and governments. Together with the increasing importance of software in all areas, which is in itself an impetus to the growth of the knowledge-based economy, this has led to an expansion of the subject matter base that must be considered by patent offices everywhere. Such expansion is not a new phenomenon - it has tended to happen whenever there are important changes in technological regimes. But it does lead to two kinds of "adjustment" problems: first, debates over the validity of the subject matter extension, such as have occurred between the U.S. and Europe over business method patents, and second, a concern that overly broad and invalid patents may issue early in the development of the technology because of the lack of prior art in the relevant patent office databases, even though such prior art may exist among those who practice the technology. The second problem, which may broadly be defined as the difficulty of determining the validity of a patent application in new and less understood technologies, is the one that an inter partes post grant review or re-examination system might be designed to address.

In order to understand how such a system might work, the analysis in this paper highlights several interesting features of the patent-challenge systems of the US and EPO systems. First, the current US re-examination procedure differs dramatically from the EPO opposition procedure in virtually all of its features, of which the most significant are the identity of the party requesting a re-examination (the patent owner in more than $40 \%$ of the cases) and the outcomes, which are rarely revocation of the patent. These characteristics of re-examination hardly qualify it as the sort of adversarial procedure that EPO oppositions represent, but they are not surprising when we consider the differences in structure between the two procedures: 1) A three-examiner panel including the original examiner, but not as chair, in the EPO versus a single examiner, often the same as the original examiner, in the USPTO; 2) the bar in later litigation to questions that could have been raised in a re-exam in the US; 3 ) the inter partes nature of the proceeding at the EPO versus ex parte at the USPTO.

Keeping in mind the significant differences between the re-examination and opposition processes, our comparative analysis suggests that EPO oppositions are not significantly swifter in resolving challenges than the USPTO re-examination proceedings, as might be expected given their more adversarial nature. Indeed, opposition proceedings in some 
cases (and almost certainly, in important, complex cases with numerous opponents, appeals, etc.) may well take as much time to be resolved as litigation in the US system. Nonetheless, the higher frequency of opposition (which is presumably due to the lower cost associated with opposition as compared to the cost of litigation in the US) within the EPO system suggests that this process handles many more legal disputes over patent validity than are addressed by the U.S. re-examination process.

Our analysis also indicates that patent amendment, rather than revocation, is more likely for oppositions in relative new fields of inventive activity, for more "complex" patents, or for oppositions in which numerous opponents participate. Since we lack evidence on the extent to which oppositions are followed by litigation in the European patent system, we cannot determine whether the lack of any advantage for oppositions in resolving patent disputes quickly is offset by a reduction of litigation rates associated with oppositions. The EPO system may offer few advantages over the U.S. system for post-issue patent challenges, but we cannot address this issue without analyzing litigation data for both the U.S. and European systems Any comprehensive assessment of the social costs and benefits of the two challenge systems requires that we consider both the "patent office" processes of post-grant challenge (opposition or re-examination) and litigation.

Nevertheless, the preliminary computations present here do suggest that the social gains from such a system might be substantial.

\section{REFERENCES}

AIPLA (American Intellectual Property Law Association) 1999, 2001. "Report of Economic Survey," Washington, D.C.

Allison, J. R., M. A. Lemley, K.A. Moore, and R. D. Trunkey. 2003. "Valuable Patents," UT Austin, UC Berkeley, and George Mason University: Draft manuscript.

Allison, J. R. and M. Lemley. 2002. "The Growing Complexity of the United States Patent System," Boston University Law Review 82 (1): 77-144.

Allison, J. R. and E. H. Tiller. 2003."Statistical Analysis of Internet Business Method Patents." Intellectual Property in the Knowledge-Based Economy. W. M. Cohen. Washington, DC, National Academies Press.

Barton, J. H. 2000. "Reforming the Patent System.” Science 287: 1933-1934.

Cremers, K. 2003. "Determinants of Patent Litigation in Germany," paper presented at the ZEW Workshop on the Empirical Economics of Innovation and Patenting, Mannheim, Germany, March 14-15, 2003.

EPO (European Patent Office) 1999. Annual Report. Munich, Germany.

Graham, J. H. S. and D. C. Mowery. 2002. "Intellectual Property Protection in the U.S. Software Industry.” Haas School, UC Berkeley: Berkeley, CA.

Graham, J. H. S., B. H. Hall, D. Harhoff, and D. C. Mowery. 2003.

Hall, B. H. 2003. "Business Method Patents and Innovation," Paper prepared for the Atlanta Federal Reserve Bank Conference on Business Method Patents, April 2003. 
Hall, B. H., and R. H. Ziedonis. 2001. "The Patent Paradox Revisited: An Empirical Study of Patenting in the U.S. Semiconductor Industry, 1979-1995." Rand Journal of Economics 32: 101-128.

Harhoff, D. 2003. "Patent Opposition in Europe: An Analysis of Incidence, Duration, and Outcomes across Technological Fields," paper presented at the ZEW Workshop on the Empirical Economics of Innovation and Patenting, Mannheim, Germany, March 14-15, 2003.

Harhoff, D., and B. H. Hall. 2002. "Intellectual Property Strategy in the Global Cosmetics Industry," Ludwig-Maximilians Universitaet and UC Berkeley.

Harhoff, D., F. M. Scherer and K. Vopel 2003. "Citations, Family Size, Opposition and the Value of Patent Rights - Evidence from Germany", forthcoming in Research Policy.

Harhoff, D. and M. Reitzig 2001. "Determinants of Opposition against EPO Patent Grants - The Case of Biotechnology and Pharmaceuticals.” Muenchen: Ludwig-MaximiliansUniversitaet.

Hunt, R. M. 2001. "You Can Patent That? Are Patents on Computer Programs and Business Methods Good for the New Economy?" Philadelphia Federal Reserve Bank Business Review, 2001:Q1: 5-15.

Janis, M. D. 1997. "Rethinking Reexamination: Toward a Viable Administrative Revocation System for U.S. Patent Law." Harvard Journal of Law and Technology 11(1): 1-122.

Kingston, W. 2001. "Innovation Needs Patents Reform," Research Policy 30: 403-423.

Kortum, S. and J. Lerner 1999. "Stronger Patent Protection or Technological Revolution: What is behind the Recent Surge in Patenting?" NBER Working paper 6204.

Lanjouw, J. O., and M. Schankerman 2002. "Enforcing Patent Rights: An Empirical Study," Brookings Institution and LSE (August).

Lanjouw, J. O., and M. Schankerman 2001. "Enforcing Intellectual Property Rights," NBER working paper 8656 (December).

Lemley, M. A., and J. R. Allison 1998. "Empirical Evidence on the Validity of Litigated Patents," Am. Intell. Prop. Law Association Quarterly Journal 185: 26.

Lemley, M. A. 2001. "Rational Ignorance at the Patent Office." Northwestern University Law Review 95(4): 1495-532.

Lerner, J. 1995. "Patenting in the Shadow of Competitors." Journal of Law and Economics 38(2): 463-96.

Levin, R. C. and J. Levin. 2002. "Patent Oppositions." Yale University and Stanford University: New Haven and Palo Alto.

Lunney, G. S., Jr. 2001. “e-Obviousness.” Michigan Telecommunications Technology Law Review 7: 363-422.

Magrab, E. B. 1993. "Patent Validity Determinations of the ITC: Should U.S. District Grant Them Preclusive Effect?" Journal of the Patent \& Trademark Office Society 75(125): 12735.

Merges, R. P. 1997. Patent Law and Policy. Charlottesville, VA: Michie.

Merges, R. P., P. Menell, M. Lemley, and T. Jorde. 1997. Intellectual Property in the New Technological Age. New York: Aspen. 
Merges, R. P. 1999. “As Many as Six Impossible Patents Before Breakfast: Property Rights for Business Concepts and Patent System Reform." Berkeley High Technology Law Journal 14: 577-615.

Michel, J. and B. Bettels 2001. "Patent citation analysis - a closer look at the basic input data from patent research reports." Scientometrics 51: 181-201.

Neifeld, R. 2000. "Analysis Of The New Patent Laws Enacted November 29, 1999." Journal of the Patent and Trademark Office Society 82: 181.

Somaya, D. 2002. "Patent Litigation in the United States (1970-2000)," Chapter 2 of a Ph.D. Thesis, Haas School of Business, UC Berkeley.

Stauder, D. 1989. Patent- und Gebrauchsmusterverletzungsklagen in der Bundesrepublik Deutschland, Großbritannien, Frankreich und Italien. Schriftenreihe zum Gewerblichen Rechtsschutz (Vol. 89), Max-Planck-Institut für ausländisches und internationales Patent-, Urheber- und Wettbewerbsrecht. Köln.

Stauder, D. 1996. "Aspekte der Durchsetzung gewerblicher Schutzrechte: Fachkundiger Richter, schnelles Verfahren und europaweites Verletzungsgebot," in: J. Straus (ed.) Aktuelle Herausforderungen des geistigen Eigentums. Köln.

Stauder, D., P. von Rospatt, and M. von Rospatt. 1999. "Protection transfrontalière des brevets europeéns." Revue Internationals de Droit Economique 1: 119-133.

Straus, J. 1996. "Die Aufrechterhaltung eines europäischen Patents in geändertem Umfang im Einspruchsverfahren und ihre Folgen," in: J. Straus (ed.) Aktuelle Herausforderungen des geistigen Eigentums. Köln, pp. 171-184. 
Table 1

Some Examples of Patents Whose Validity has been Questioned

\begin{tabular}{|c|c|c|c|c|}
\hline $\begin{array}{c}\text { Patent } \\
\text { Number }\end{array}$ & $\begin{array}{c}\text { Year } \\
\text { Granted }\end{array}$ & Assignee & Title & Description \\
\hline $5,241,671$ & 1993 & $\begin{array}{l}\text { Encylopaedia } \\
\text { Britannica (Compton) }\end{array}$ & $\begin{array}{l}\text { Multimedia search system using a plurality of } \\
\text { entry path means which indicate } \\
\text { interrelatedness of information }\end{array}$ & $\begin{array}{l}\text { broad claims that cover a multimedia CD-ROM } \\
\text { that searches multiple databases of text, images, } \\
\text { and video }\end{array}$ \\
\hline $5,797,127$ & 1998 & $\begin{array}{l}\text { Walker Asset } \\
\text { Management LP/ } \\
\text { Priceline }\end{array}$ & $\begin{array}{l}\text { Method, apparatus, and program for pricing, } \\
\text { selling, and exercising options to purchase } \\
\text { airline tickets }\end{array}$ & $\begin{array}{l}\text { An algorithm for constructing airline ticket option } \\
\text { prices based on past demand, implemented on a } \\
\text { computer }\end{array}$ \\
\hline $5,937,468$ & 1999 & Lucent & Sine/cosine table lookup on a computer & $\begin{array}{l}\text { use of a computer algorithm to perform the table } \\
\text { lookup familiar from math textbooks to obtain the } \\
\text { sine or cosine of an angle }\end{array}$ \\
\hline $5,963,916$ & 1999 & Intouch Group, Inc. & $\begin{array}{l}\text { Network apparatus and method for preview of } \\
\text { music products and compilation of market } \\
\text { data }\end{array}$ & $\begin{array}{l}\text { patent on storing music on a server (with backup } \\
\text { servers) and letting users listen to it by clicking on } \\
\text { a list of music available }\end{array}$ \\
\hline $6,257,248$ & 2001 & NA & Both hand hair cutting method & $\begin{array}{l}\text { Cutting or styling hair using instruments such as } \\
\text { scissors or combs in both hands }\end{array}$ \\
\hline $6,368,227$ & 2002 & NA & Method of swinging on a swing & $\begin{array}{l}\text { swinging a swing sideways or in a circular motion } \\
\text { instead of back and forth by pulling on the chains } \\
\text { (re-examined in 2003) }\end{array}$ \\
\hline
\end{tabular}


Table 2

Outcomes from Oppositions (EPO) and Re-examinations (USPTO)

\begin{tabular}{|c|c|c|c|c|c|c|}
\hline \multirow[b]{2}{*}{ Outcome } & \multicolumn{2}{|c|}{ Opposition* } & \multicolumn{2}{|c|}{ Re-examination** } & \multicolumn{2}{|c|}{$\begin{array}{l}\text { Re-examination, }{ }^{* *} \\
\text { excluding owner- } \\
\text { requested re-exams }\end{array}$} \\
\hline & Total number & Total share & Total number & Total share & Total number & Total share \\
\hline No change to patent & 5,590 & $22.4 \%$ & 716 & $23.9 \%$ & 476 & $25.9 \%$ \\
\hline Patent amended & 6,466 & $33.0 \%$ & 1,993 & $66.4 \%$ & 1,151 & $62.7 \%$ \\
\hline Patent revoked & 6,655 & $35.1 \%$ & 291 & $9.7 \%$ & 209 & $11.4 \%$ \\
\hline Closed/no outcome & 1,753 & $9.6 \%$ & 0 & $0.0 \%$ & 0 & $0.0 \%$ \\
\hline Total with an outcome & 20,464 & $100.0 \%$ & 3,000 & $100.0 \%$ & 1,836 & $100.0 \%$ \\
\hline $\begin{array}{l}\text { Pending } \\
\text { Total }\end{array}$ & $\begin{array}{c}3,221 \\
23,685\end{array}$ & $22.4 \%$ & $\begin{array}{c}902 \\
3,902\end{array}$ & $23.1 \%$ & $\begin{array}{c}472 \\
2,308\end{array}$ & $20.5 \%$ \\
\hline
\end{tabular}

*Opposition outcomes are for all patents granted by the EPO 1980-1999, oppositions filed 1980-Sept. 2000.

${ }^{* *}$ Re-examination outcomes are for all re-exams filed between 1981 and 1998

Each re-exam appears only once. In the cases where there is more than one re-examination request

the outcomes have been combined. 
Table 3

Estimated Patent Costs in the United States and Europe

\begin{tabular}{|l|c|c|}
\hline & United States & Europe \\
\hline Application $_{\text {Fees }}$ & $\$ 34,000$ & $\$ 22,903$ \\
Legal costs $^{\text {Translation }}$ & $\$ 4,000$ & $\$ 4,624$ \\
\hline Renewal (10 years) & $\$ 30,000$ & $\$ 5,914$ \\
\hline Re-examination/Opposition & $\mathrm{NA}$ & $\$ 12,366$ \\
\hline Fees & $\$ 6,000$ & $\$ 9,140$ \\
$\quad$ Legal costs & $\$ 2,520$ & \\
\hline Litigation & $\$ 10,000-\$ 100,000$ & $\$ 1,075$ \\
\hline
\end{tabular}

*These fees are for a non-small entity.

Numbers are in $2002 \$$, using an exchange rate of 0.93 euros to the dollar.

Figures are approximate. 
Table 4

Welfare Computation under Different Scenarios

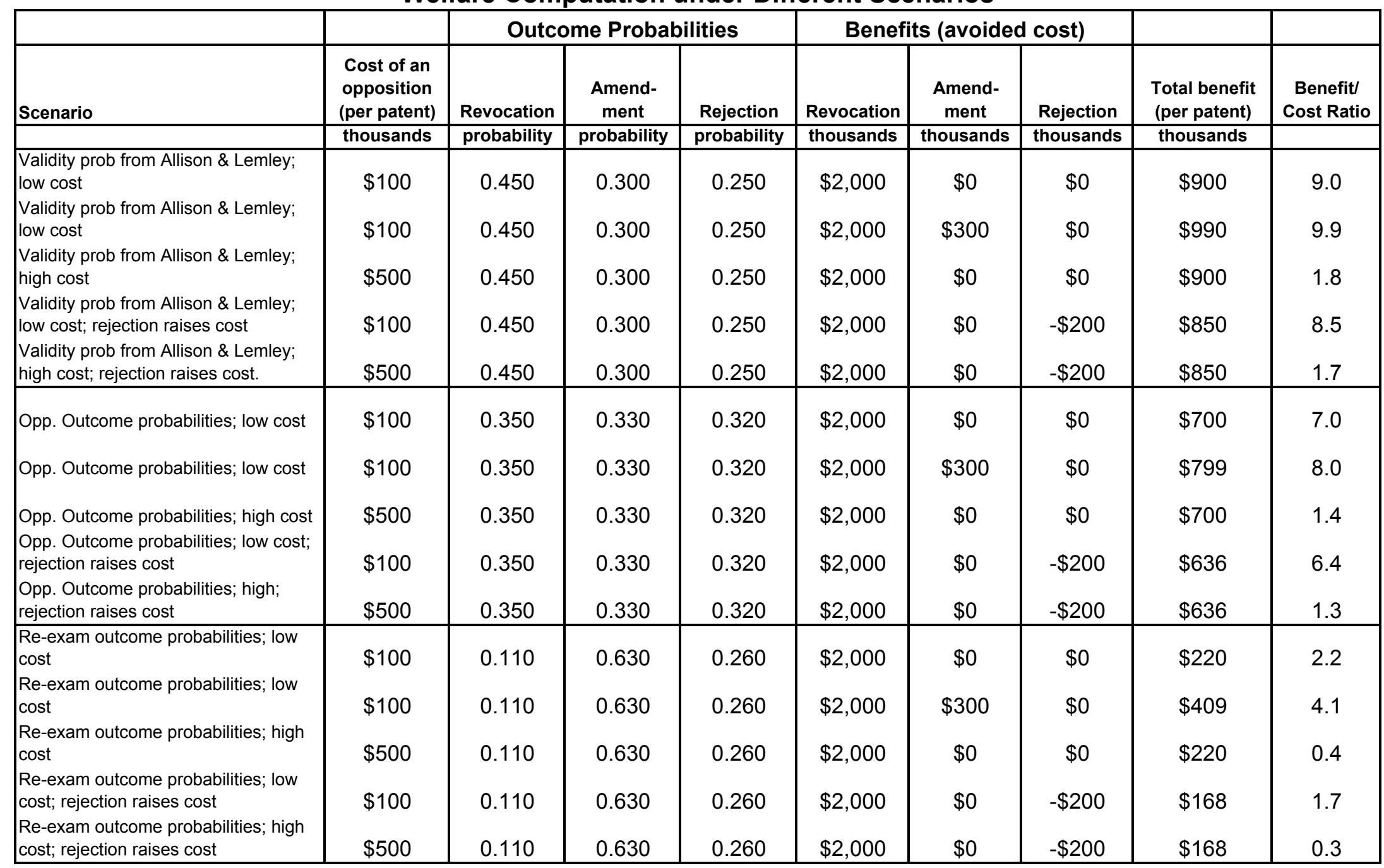


Figure 1

USPTO Utility Patents 1965-2002

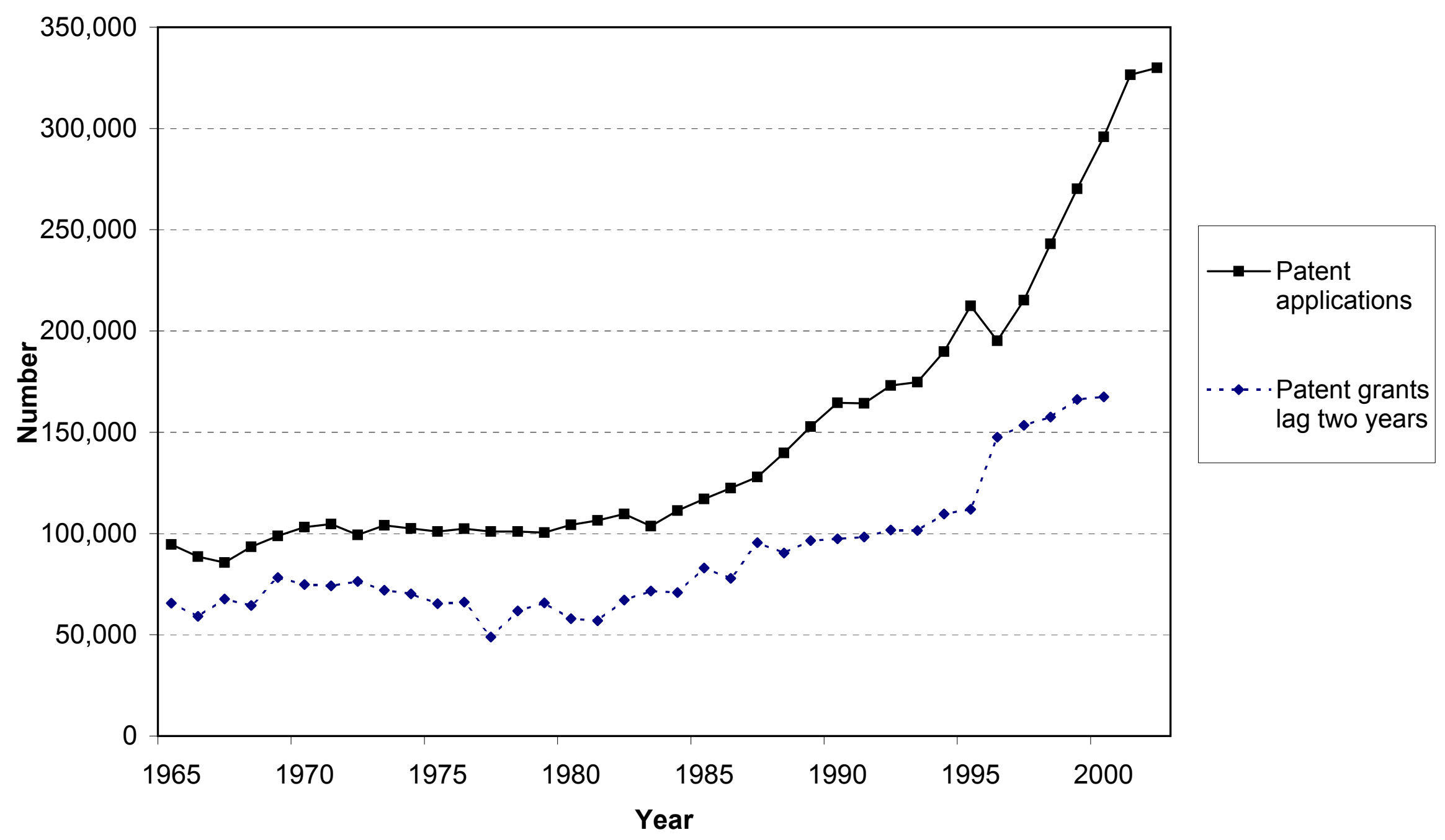

